\title{
ANALISIS FAKTOR-FAKTOR YANG MEMPENGARUHI OPINI AUDIT GOING CONCERN PADA PERUSAHAAN MANUFAKTUR YANG TERDAFTAR DI BURSA EFEK INDONESIA
}

\author{
Widya Febryari Anita
}

\begin{abstract}
The goals of this research is to show the influence of liquidity, leverage, profitability, cash flow from operations, size, growth company, audit quality, audit lag, client tenure, debt default to the acceptance of going concern audit opinion at manufacture company listed on Indonesia Stock Exchange between 2010 to 2013. The population of this research are 148 manufacture companies. Sampling method that used in this research is purposive sampling, so I get 25 company samples to 4 years (20102013) with 100 analysis units by access the financial statement of auditee, independent audit report, and annual report on website www.idx.co.id. Analysis data technique that is used in this research is descriptive statistics analysis and logistic regression method. The results of this research indicate that. Leverage and audit lag has positive influence to the acceptance of going concern audit opinion. While other variable, cash flow from operations has negative influence to the acceptance of going concern audit opinion. Liquidity, profitability, size, growth company, audit quality, auditor client tenure, debt default has insignificantly influence to the acceptance of going concern audit opinion.
\end{abstract}

Keywords: Liquidity, Leverage, Profitability, Cash Flow From Operation, Size, Growth Company, Audit Quality, Audit lag, Audit Client Tenure, Debt Default, and Going Concern Audit Opinion

\section{PENDAHULUAN}

Tujuan dari keberadaan suatu entitas ketika didirikan adalah untuk mempertahankan kelangsungan hidup (going concern) usahanya melalui asumsi going concern. Opini audit going concern merupakan opini yang dikeluarkan auditor untuk memastikan apakah perusahaan dapat mempertahankan kelangsungan hidupnya (SPAP, 2011). Kelangsungan hidup usaha selalu dihubungkan dengan kemampuan manajemen dalam mengelola perusahaan agar bertahan hidup. Di Indonesia, isu mengenai laporan auditor dan hubungannya dengan masalah kelangsungan hidup perusahaan sudah timbul sejak tahun 1995. Isu ini muncul ditandai dengan runtuhnya Bank Summa, meskipun bank telah mengeluarkan laporan audit yang disajikan secara wajar pada tahun sebelumnya, ternyata tidak menjamin kelangsungan hidup entitas tersebut. Sejak terjadinya krisis ekonomi tahun 1997 di Indonesia, isu kelangsungan hidup perusahaan semakin menjadi sorotan publik. Perekonomian mengalami keterpurukan, sehingga banyak perusahaan yang bangkrut karena tidak bisa melanjutkan usahanya. Bukti menunjukkan bahwa, pada tahun 1997 sebanyak 14 perusahaan dan 15 
perusahaan ditahun 1998 telah mengeluarkan laporan audit yang disajikan secara wajar pada tahun sebelumnya, namun runtuh pada tahun berikutnya . Dalam suatu opini audit laporan keuangan yang baik (unqualified opinion), auditor harus mengemukakan bahwa laporan keuangan perusahaan telah diaudit sesuai dengan prinsip akuntansi yang berlaku umum di Indonesia dan tidak ada penyimpangan material yang dapat mempengaruhi pengambilan suatu keputusan. Dalam mengeluarkan opini audit suatu perusahaan, auditor harus memperhatikan beberapa faktor.

Likuiditas suatu perusahaan sering ditunjukkan oleh current ratio yaitu membandingkan aktiva lancar dengan kewajiban lancar. Makin rendah nilai current ratio menunjukkan semakin rendah kemampuan perusahaan dalam menutupi kewajiban jangka pendeknya (Widyantari, 2011). Ada beberapa peneliti (Yulius, 2009; Masyitoh dan Adhariani, 2010; Widyantari, 2011; Warnida, 2011), rasio yang digunakan ini untuk mengukur likuiditas suatu perusahaan dengan menggunakan current ratio dalam penelitian mereka. Penelitian Warnida (2011), hasil penelitiannya menunjukkan bahwa likuiditas yang menggunakan current ratio berpengaruh terhadap penerimaan opini going concern. Namun penelitian yang dilakukan oleh Yulius (2009), Masyitoh dan Adhariani (2010), Widyantari (2011) menemukan bahwa rasio likuiditas tidak berpengaruh signifikan pada penerimaan opini audit going concern.

Kerugian usaha yang besar secara berulang atau kekurangan modal kerja, serta ketidakmampuan perusahaan untuk memenuhi kewajibannya pada saat jatuh tempo, mencerminkan kondisi keuangan perusahaan yang bermasalah. Rasio leverage dapat digunakan untuk mengetahui kapasitas perusahaan dalam memenuhi kewajiban baik itu jangka pendek maupun jangka panjang. Rasio leverage umumnya diukur dengan menggunakan debt ratio yaitu membandingkan total kewajiban dengan total aktiva. Jumlah utang yang melebihi total aktiva menyebabkan perusahaan mengalami defisiensi modal atau saldo ekuitas bernilai negatif. Semakin tinggi rasio leverage menunjukkan kinerja keuangan perusahaan yang semakin buruk dan dapat menimbulkan ketidakpastian mengenai kelangsungan hidup perusahaan. Perusahaan yang memiliki nilai aset yang lebih kecil daripada hutangnya akan menghadapi bahaya kebangkrutan (Yulius, 2009). Penelitian yang dilakukan oleh Yulius (2009), Masyitoh dan Adhariani (2010), Widyantari (2011) yang menunjukkan bahwa leverage berhubungan positif dengan pemberian opini audit going concern.

Menurut Sartono (2001:122) yang dikutip oleh Widyantari (2011), Profitabilitas adalah kemampuan perusahaan memperoleh laba dalam hubungannya dengan penjualan, total aktiva, maupun modal sendiri. Profitabilitas dapat diukur dengan rasio laba bersih sebelum pajak dibagi penjualan bersih (NIBTS). Semakin besar rasio ini menunjukkan kinerja perusahaan yang semakin baik untuk menghasilkan laba sehingga tidak menimbulkan keraguan auditor akan kemampuan 
perusahaan untuk melanjutkan usahanya dan dapat memperkecil kemungkinan penerimaan opini going concern. Penelitian Widyantari (2011) yang menemukan bahwa rasio ini berpengaruh negatif signifikan untuk memprediksi pembuatan keputusan opini going concern. Mills dan Yamamura (1998) dalam Widyantari (2011) menyatakan bahwa untuk memahami secara keseluruhan kemampuan perusahaan dalam melanjutkan usahanya, auditor harus memperhitungkan beberapa rasio sederhana dari data laporan arus kas klien. Namun hasil penelitian Masyitoh dan Adhariani (2010) menunjukkan bahwa profitabilitas tidak berpengaruh pada pemberian opini audit going concern.

Salah satu rasio arus kas yang dapat digunakan oleh auditor untuk menilai kemampuan perusahaan dalam melanjutkan usahanya adalah cash flow to total debt ratio. Penelitian yang dilakukan Widyantari (2011) menemukan bahwa cash flow to total debt ratio berpengaruh negatif signifikan pada opini audit going concern. Namun penelitian yang dilakukan oleh Masyitoh dan Adhariani (2010), Agustina (2013) menemukan bahwa rasio arus kas tidak berpengaruh signifikan pada opini audit going concern.

Untuk kondisi dengan risiko litigasi rendah seperti Hongkong dan negara di Asia Tenggara pada umumnya, Kevin et al. (2006) dalam Widyantari(2011) menyatakan bahwa perusahaan besar memiliki kemampuan yang lebih baik dalam mempertahankan kelangsungan hidupnya bahkan ketika perusahaan mengalami financial distress. Oleh karena itu, auditor akan menunda untuk mengeluarkan opini audit going concern dengan harapan bahwa perusahaan akan dapat mengatasi kondisi buruk pada tahun mendatang. Hasil penelitian Widyantari(2011), Warnida (2011) membuktikan bahwa ukuran perusahaan memberikan pengaruh negatif signifikan pada opini audit going concern. Namun penelitian Dewayanto (2011), Rahman dan Siregar (2012) membuktikan bahwa ukuran perusahaan tidak berpengaruh signifikan pada penerimaan opini audit going concern.

Pertumbuhan perusahaan mengindikasikan kemampuan perusahaan dalam mempertahankan kelangsungan usahanya. Perusahaan yang mengalami pertumbuhan menunjukkan aktivitas operasional perusahaan berjalan dengan semestinya sehingga perusahaan dapat mempertahankan posisi ekonominya dan kelangsungan hidupnya, sedangkan perusahaan dengan negative growth mengindikasikan kecenderungan yang lebih besar ke arah kebangkrutan (Altman, 1968) dalam Widyantari (2011). Penelitian Widyantari (2011), Putrady (2012), Yunida (2013), menemukan koefisien positif dan tidak signifikan terhadap penerimaan opini audit going concern. Penelitian Solikhah dan Kiswanto (2010), Suryani (2014) hasil pengujiannya menunjukkan bahwa pertumbuhan perusahaan memiliki koefisien regresi negatif dan tidak berpengaruh pada opini audit going concern. Sedangkan Penelitian Kartika (2012), Rahman dan Siregar (2012) menunjukkan bahwa pertumbuhan perusahaan berpengaruh negatif dan 
signifikan terhadap penerimaan opini audit going concern.

DeAngelo (1981) dalam Widyantari (2011) menyimpulkan bahwa Kantor Akuntan Publik (KAP) yang lebih besar dapat diartikan menghasilkan kualitas audit yang lebih baik dibandingkan kantor akuntan kecil. Selain itu, KAP skala besar memiliki insentif yang lebih besar untuk menghindari kritikan kerusakan reputasi dibandingkan KAP skala kecil. KAP skala besar lebih cenderung untuk mengungkapkan masalah-masalah yang ada karena mereka lebih kuat menghadapi risiko proses pengadilan. Penelitian Mutchler et al (1997) dalam Yunida (2013) menemukan bukti univariat bahwa auditor Big 6 lebih cenderung menerbitkan opini audit going concern pada perusahaan yang mengalami financial distress dibandingkan auditor non-Big 6. Namun penelitian Praptitorini dan Januarti (2011), Widyantari (2011), Kartika (2012), Yunida (2013) menemukan bahwa kualitas audit tidak berpengaruh signifikan pada opini audit going concern.

Ashton et al. (1987) dalam Widyantari (2011) menyatakan bahwa perusahaan yang menerima opini going concern membutuhkan waktu audit yang lebih lama dibandingkan perusahaan yang menerima opini tanpa kualifikasi. Penelitian yang dilakukan Astuti (2012), Hasanah (2014) menemukan hubungan positif antara audit lag yang panjang dengan opini audit going concern. McKeown et al. (1991) dalam Astuti (2012) menyatakan bahwa opini audit going concern lebih banyak ditemui ketika pengeluaran opini terlambat. Hal ini mungkin terjadi karena auditor lebih banyak melakukan pengujian, manajer melakukan negosiasi yang panjang ketika terdapat ketidakpastian kelangsungan usaha, dan auditor berharap bahwa perusahaan dapat mengatasi masalah yang dihadapi untuk menghindari dikeluarkannya opini audit going concern. Namun penelitian yang dilakukan oleh Widyantari (2011), Putrady (2012) menemukan bahwa audit lag tidak berpengaruh signifikan pada penerimaan opini audit going concern.

Auditor client tenure atau audit firm tenure merupakan jangka waktu perikatan yang terjalin antara Kantor Akuntan Publik (KAP) dengan auditee yang sama. Kecemasan akan kehilangan sejumlah fee yang cukup besar akan menimbulkan keraguan bagi auditor untuk menyatakan opini audit going concern. Dengan demikian independensi auditor akan terpengaruh dengan lamanya hubungan dengan auditee yang sama (Espahbodi, 1991 dalam Januarti, 2009). Penelitian yang dilakukan oleh Januarti (2009) menemukan bahwa auditor client tenure berpengaruh negatif pada penerimaan opini audit going concern. Namun penelitian Widyantari (2011), Dewayanto (2011), Putrady (2012) menemukan bahwa auditor client tenure tidak memiliki pengaruh signifikan pada penerimaan opini audit going concern.

Chen dan Church (1992) dalam Myrna dan Januarti (2011), Debt Default didefinisikan sebagai kegagalan debitor (perusahaan) untuk membayar hutang pokok dan/atau bunganya pada waktu jatuh tempo. Apabila perusahaan gagal dalam membayar utang (debt default) maka kelangsungan usahanya menjadi 
diragukan, oleh sebab itu kemungkinannya auditor akan memberi opini audit going concern. Penelitian Praptitorini dan Januarti (2011), Astuti (2012) menunjukkan bahwa debt default berpengaruh positif terhadap penerimaan opini audit going concern. Namun penelitian Yulius (2009) dan Agustina (2013) menunjukkan bahwa debt default tidak berpengaruh terhadap penerimaan opini audit going concern.

Berdasarkan latar belakang tersebut peneliti termotivasi melakukan penelitian kembali mengenai faktor-faktor yang mempengaruhi opini audit going concern yaitu likuiditas, leverage, profitabilitas, ukuran perusahaan, audit lag, dan auditor client tenure, serta debt default.

Penelitian ini merupakan replikasi dari penelitian yang dilakukan oleh A.A Putri Widyantari (2011) yang meneliti "Opini audit going concern dan faktorfaktor yang memengaruhi: Studi pada Perusahaan Manufaktur di Bursa Efek Indonesia". Perbedaan penelitian ini dengan penelitian A.A Putri Widyantari (2011) adalah penelitian Widyantari (2011) menggunakan perusahaan manufaktur yang terdaftar di Bursa Efek Indonesia periode 2000-2009. Faktorfaktor yang diuji dalam penelitian Widyantari (2011) adalah likuiditas, leverage, profitabilitas, arus kas, ukuran perusahaan, pertumbuhan perusahaan, kualitas audit, audit lag, opini audit tahun sebelumnya, dan auditor client tenure. Sedangkan peneliti melakukan pengujian kembali mengenai faktor-faktor yang mempengaruhi opini audit going concern yaitu likuiditas, leverage, profitabilitas, arus kas, ukuran perusahaan, pertumbuhan perusahaan, kualitas audit, audit lag, dan auditor client tenure, serta debt default sebagai sampel penelitian dengan menggunakan perusahaan manufaktur yang terdaftar di Bursa Efek Indonesia periode tahun 2010-2013. Berdasarkan ruang lingkup dan identifikasi masalah yang telah diuraikan diatas, maka dapat dibuat perumusan masalah dalam penelitian ini adalah :

1. Apakah terdapat pengaruh Likuiditas terhadap opini audit going concern pada perusahaan manufaktur yang terdaftar di BEI?

2. Apakah terdapat pengaruh Leverage terhadap opini audit going concern pada perusahaan manufaktur yang terdaftar di BEI?

3. Apakah terdapat pengaruh Profitabilitas terhadap opini audit going concern pada perusahaan manufaktur yang terdaftar di BEI?

4. Apakah terdapat pengaruh Arus Kas terhadap opini audit going concern pada perusahaan manufaktur yang terdaftar di BEI?

5. Apakah terdapat pengaruh Ukuran Perusahaan terhadap opini audit going concern pada perusahaan manufaktur yang terdaftar di BEI?

6. Apakah terdapat pengaruh Pertumbuhan Perusahaan terhadap opini audit going concern pada perusahaan manufaktur yang terdaftar di BEI?

7. Apakah terdapat pengaruh Kualitas Audit terhadap opini audit going concern pada perusahaan manufaktur yang terdaftar di BEI?

8. Apakah terdapat pengaruh Audit Lag terhadap opini audit going concern pada perusahaan manufaktur yang terdaftar di BEI? 
9. Apakah terdapat pengaruh Auditor Client Tenure terhadap opini audit going concern pada perusahaan manufaktur yang terdaftar di BEI?

10. Apakah terdapat pengaruh Debt Default terhadap opini audit going concern pada perusahaan manufaktur yang terdaftar di BEI?

\section{TINJAUAN TEROTIS DAN HIPOTESIS}

Teori Agensi. Menurut Jensen dan Meckling (1976) dalam Widyantari (2011), bahwa agency theory mendeskripsikan pemegang saham sebagai principal dan manajemen sebagai agen. Manajemen merupakan pihak yang dikontrak oleh pemegang saham untuk bekerja demi kepentingan pemegang saham. Untuk itu manajemen diberikan sebagian kekuasaan untuk membuat keputusan bagi kepentingan terbaik pemegang saham. Oleh karena itu, manajer harus bertanggungjawab kepada pemegang saham. Unit analisis yang digunakan dalam teori keagenan adalah kontrak yang melandasi hubungan antara principal dan agen. Fokusnya adalah penentuan kontrak yang paling efisien yang mendasari hubungan agen dan principal. Kontrak yang efisien adalah kontrak yang memenuhi dua faktor, yaitu: (1) Agen dan principal memiliki informasi yang simetris artinya baik agen maupun principal memiliki kualitas dan jumlah informasi yang sama sehingga tidak terdapat informasi yang disembunyikan yang dapat digunakan untuk keuntungan diri sendiri, (2) Risiko yang dipikul berkaitan dengan imbal jasanya adalah kecil, yang berarti agen mempunyai kepastian yang tinggi mengenai imbalan yang diterimanya

Auditing. ASOBAC (A Statement of Basic Auditing Concepts) yang dikutip oleh Messier et al (2014:12) mendefinisikan auditing sebagai proses sistematik untuk memperoleh dan mengevaluasi bukti-bukti audit secara objektif mengenai asersi-asersi tentang kegiatan dan peristiwa ekonomi untuk menentukan tingkat kesesuaian antara asersi-asersi tersebut dengan kriteria yang telah ditetapkan dan mengomunikasikan hasil-hasilnya kepada pihak-pihak yang berkepentingan.

Opini Audit. Opini audit diberikan auditor melalui beberapa tahap audit sehingga auditor dapat memberikan kesimpulan atas opini yang harus diberikan atas laporan keuangan yang diauditnya (Rahman dan Siregar, 2012). Opini audit dinyatakan dalam paragraf pendapat dalam laporan audit. Laporan auditor harus memuat suatu pernyataan pendapat mengenai laporan keuangan secara keseluruhan. Laporan keuangan yang dimaksud dalam standar pelaporan tersebut adalah meliputi neraca, laporan laba rugi, laporan perubahan ekuitas, laporan arus kas, dan semua catatan kaki serta penjelasan dan tambahan informasi yang merupakan bagian tidak terpisahkan dalam penyajian laporan keuangan. Oleh karena itu dalam standar laporan auditor harus menyampaikan kepada pemakai laporan mengenai informasi yang menurut auditor perlu diungkapkan. Menurut SPAP SA 700 (2011) dan SPAP SA 705 (2011), bentuk opini audit terdiri atas dua jenis, yaitu: Opini Tanpa Modifikasian dan Opini Modifikasian. 
Opini Modifikasian dapat berupa Opini Wajar dengan Pengecualian, Opini Tidak Wajar, dan Opini Tidak Menyatakan Pendapat.

Opini Audit Going Concern. Menurut Standar Profesional Akuntan Publik (SPAP) SA No. 570, pengertian opini audit going concern merupakan pertimbangan auditor atas kemampuan entitas dalam mempertahankan kelangsungan hidupnya. Going concern adalah salah satu konsep yang paling penting yang mendasari pelaporan keuangan. Merupakan tanggung jawab utama direktur untuk menentukan kelayakan dari persiapan laporan keuangan menggunakan dasar going concern dan tanggung jawab auditor untuk meyakinkan dirinya bahwa penggunaan dasar going concern oleh perusahaan adalah layak dan diungkapkan secara memadai dalam laporan keuangan Gray \& Manson (2000) dalam Dewayanto (2011).

\section{Kesimpulan Audit dan Pelaporan} Mengenai Kesinambungan Usaha. Penjelasan ISA 570 yang dikutip oleh Tuanakotta (2013:228) adalah berdasarkan bukti audit yang diperoleh, auditor harus menyimpulkan apakah, menurut pertimbangan auditor, terdapat suatu ketidakpastian material yang terkait dengan peristiwa atau kondisi yang, baik secara individual maupun kolektif, dapat menyebabkan keraguan signifikan atas kemampuan entitas dalam mempertahankan kelangsungan usahanya. Suatu ketidakpastian material terjadi ketika signifikansi dampak potensialnya dan kemungkinan terjadinya adalah sedemikian rupa yang, menurut pertimbangan auditor, pengungkapan yang tepat atas sifat dan implikasi ketidakpastian tersebut diperlukan untuk:

(a)Dalam hal kerangka penyajian laporan keuangan wajar: penyajian yang wajar atas laporan keuangan, atau

(b)Dalam hal kerangka pelaporan keuangan dengan kepatuhan, agar laporan keuangan tidak menyesatkan. (Lihat alinea A19)

Jika auditor menyimpulkan bahwa penggunaan asumsi kelangsungan usaha sudah tepat sesuai dengan kondisinya, tetapi terdapat suatu ketidakpastian material, maka auditor harus menentukan apakah laporan keuangan:

a) Menjelaskan secara memadai peristiwa atau kondisi utama yang dapat menyebabkan keraguan signifikan atas kemampuan entitas untuk mempertahankan kelangsungan usahanya dan rencana manajemen untuk menghadapi peristiwa atau kondisi tersebut; dan

b) Mengungkapkan secara jelas bahwa terdapat ketidakpastian material yang terkait dengan peristiwa atau kondisi yang dapat menyebabkan keraguan signifikan atas kemampuan entitas untuk mempertahankan kelangsungan usahanya dan, oleh karena itu, entitas tersebut kemungkinan tidak mampu unutk merealisasikan asetnya dan melunasi liabilitasnya dalam kegiatan bisnis normal. (Lihat alinea A20)

Rasio Likuiditas. Rasio likuiditas adalah rasio yang mencerminkan kemampuan suatu perusahaan untuk memenuhi kewajiban yang segera jatuh tempo 
(kurang 1 tahun). Suatu perusahaan yang mempunyai tingkat likuiditas tinggi, dapat dikatakan bahwa perusahaan yang bersangkutan memiliki kemampuan yang tinggi untuk memenuhi kewajibannya sehingga perusahaan yang bersangkutan memiliki risiko likuiditas yang rendah. Rasio likuiditas jangka pendek mengindikasikan kemampuan entitas untuk memenuhi liabilitas lancarnya. Rasio likuiditas suatu perusahaan sering ditunjukkan oleh current ratio yang mencakup seluruh aset lancar dan liabilitas lancar dan umumnya dianggap dapat diterima bila bernilai 2 banding 1 atau lebih baik. Secara umum, current ratio yang tinggi mengindikasikan kemampuan entitas membayar liabilitas lancar. Namun demikian, jika aset lancar meliputi piutang lama atau persediaan lama, rasio ini dapat terdistorsi (Messier, 2014:174).

Rasio Leverage. Rasio leverage menurut Kasmir (2014:151) merupakan rasio yang digunakan untuk mengukur sejauh mana aktiva perusahaan dibiayai dengan utang. Artinya berapa besar beban utang yang ditanggung perusahaan dibandingkan dengan aktivanya. Dalam arti luas dikatakan bahwa rasio leverage digunakan untuk mengukur kemampuan perusahaan untuk membayar seluruh kewajibannya, baik jangka pendek maupun jangka panjang apabila perusahaan dibubarkan (dilikuidasi).

Profitabilitas.

mengindikasikan kesuksesan atau kegagalan entitas untuk satu periode tertentu (Messier, 2014:176). Profitabilitas, penting untuk kelangsungan hidup sebuah perusahaan. Beberapa uji profitabilitas memfokuskan pada pengukuran kecukupan laba dengan membandingkan laba dengan item lain yang dilaporkan dalam laporan laba rugi.

Arus Kas. Menurut Standar Akuntansi Keuangan, arus kas adalah arus masuk dan arus keluar kas atau setara kas (IAI, 2015). Rasio arus kas operasi terhadap total utang menunjukkan kemampuan arus kas operasi perusahaan dalam melunasi seluruh kewajibannya, baik kewajiban lancar maupun kewajiban jangka panjang (Hery, 2015:125).

Ukuran perusahaan (firm size). Suwito dan Herawaty (2005) dalam Widyantari (2011) menyatakan bahwa ukuran perusahaan adalah suatu skala yang dapat mengklasifikasikan perusahaan menjadi perusahaan besar dan kecil menurut berbagai cara, antara lain: total aktiva atau total aset perusahaan, nilai pasar saham, rata-rata tingkat penjualan, dan jumlah penjualan.

Pertumbuhan Perusahaan. Menurut Kasmir (2014:114), rasio pertumbuhan (growth ratio) merupakan rasio yang menggambarkan kemampuan perusahaan dalam mempertahankan posisi ekonominya di tengah pertumbuhan perekonomian dan sektor usahanya. Penjualan merupakan kegiatan operasi utama perusahaan. Penjualan perusahaan yang meningkat dari tahun ke tahun memberi peluang perusahaan untuk memperoleh peningkatan laba. Oleh karena itu, semakin tinggi rasio pertumbuhan penjualan perusahaan akan semakin kecil kemungkinan auditor 
untuk menerbitkan opini audit going concern (Setyarno dkk., 2006) dalam Kartika (2012).

Kualitas Audit. Craswell et al. (1995) dalam Widyantari (2011) menyatakan klien biasanya mempersepsikan bahwa auditor yang berasal dari KAP besar dan yang memiliki afiliasi dengan KAP internasional akan memiliki kualitas yang lebih tinggi karena auditor tersebut memiliki karakteristik yang dapat dikaitkan dengan kualitas, seperti pelatihan, pengakuan internasional, dan adanya peer review. Auditor yang memiliki reputasi yang baik akan cenderung untuk mempertahankan kualitas auditnya agar reputasinya terjaga dan tidak kehilangan klien. DeAngelo(1981) dalam Yunida (2013) menyatakan bahwa auditor skala besar memiliki insentif untuk menghindari kritikan kerusakan reputasi dibandingkan pada auditor skala kecil. Auditor skala besar juga lebih cenderung untuk mengungkapkan masalah-masalah yang ada karena mereka lebih kuat menghadapi risiko proses pengadilan. Argumen tersebut berarti bahwa auditor skala besar memiliki insentif lebih untuk mendeteksi dan melaporkan going concern kliennya. KAP skala besar lebih cenderung untuk mengungkapkan masalah-masalah yang ada karena mereka lebih kuat menghadapi risiko proses pengadilan. Argumen ini menunjukkan bahwa KAP besar memiliki insentif lebih untuk mendeteksi dan melaporkan masalah kelangsungan usaha kliennya. Palmrose (1988) dalam Widyantari (2011) membuktikan di dalam penelitiannya bahwa kelompok auditor
Big 8 memiliki tingkat litigasi yang rendah dibandingkan non-Big 8 , hal tersebut menunjukkan bahwa auditor Big 8 memberikan kualitas yang lebih tinggi karena memiliki motivasi untuk menjaga reputasinya.

Audit Lag. Audit lag atau dalam beberapa penelitian disebut sebagai audit delay didefinisikan sebagai rentang waktu penyelesaian pelaksanaan audit laporan keuangan tahunan yang diukur berdasarkan lamanya hari yang dibutuhkan untuk memperoleh laporan auditor independen atas audit laporan keuangan tahunan perusahaan sejak tanggal tahun tutup buku, yaitu per 31 Desember sampai tanggal yang tertera di laporan auditor independen (Suryani, 2014). Penelitian Astuti (2012) menyatakan audit lag adalah jumlah kalender antara tanggal disusunnya laporan keuangan dengan tanggal selesainya pekerjaan lapangan. Oleh karena itu, semakin panjang audit lag semakin lama auditor dalam menyelesaikan pekerjaan auditnya. Menurut KEP-431/BL/2012 Peraturan Nomor X.K.6, bahwa laporan keuangan tahunan wajib disampaikan kepada Bapepam dan LK dan diumumkan kepada masyarakat paling lambat pada akhir bulan ketiga (90 hari) setelah tanggal laporan keuangan tahunan.

Auditor Client Tenure. Auditor client tenure adalah lamanya waktu auditor tersebut secara berturut-turut telah melakukan pekerjaan audit terhadap suatu perusahaan. Dalam terminologi Peraturan Menteri Keuangan No. 17/PMK.01/2008 auditor tenure identik dengan masa 
pemberian jasa bagi akuntan publik. Menteri Keuangan RI pada tanggal 5 Februari 2008 menerbitkan Peraturan Menteri Keuangan No. 17/PMK.01/2008 tentang Jasa Akuntan Publik yang merupakan penyempurnaan Keputusan Menteri Keuangan No. 423/KMK.06/2002 dan No. 359/KMK.06/2003 yang dianggap sudah tidak memadai. Dalam Peraturan Menteri Keuangan tersebut terdapat pokok-pokok penyempurnaan peraturan mengenai pembatasan masa pemberian jasa bagi akuntan, laporan kegiatan, dan asosiasi profesi akuntan publik. Khususnya hal yang berhubungan dengan pembatasan masa pemberian jasa bagi akuntan publik, terdapat perubahan dimana sebelumnya Keputusan Menteri Keuangan No. 423/KMK.06/2002 dan No. 359/KMK.06 /2003 menyatakan KAP dapat memberikan jasa audit umum paling lama untuk 5 (lima) tahun buku berturut-turut kemudian dalam Pasal 3 Peraturan Menteri Keuangan No. 17/PMK.01/2008 diubah menjadi 6 (enam) tahun buku berturut-turut

Debt Default. Debt default didefinisikan sebagai kegagalan debitor (perusahaan) untuk membayar hutang pokok dan/atau bunganya pada waktu jatuh tempo (Chen dan Church 1992) dalam Myrna dan Januarti (2011).

\section{Rerangka Konseptual}

Berdasarkan teori yang telah dipaparkan sebelumnya dan hasil penemuan dari penelitian-penelitian terdahulu tentang faktor-faktor yang mempengaruhi pengungkapan going concern perusahaan maka dibuat suatu kerangka penelitian sebagai berikut:

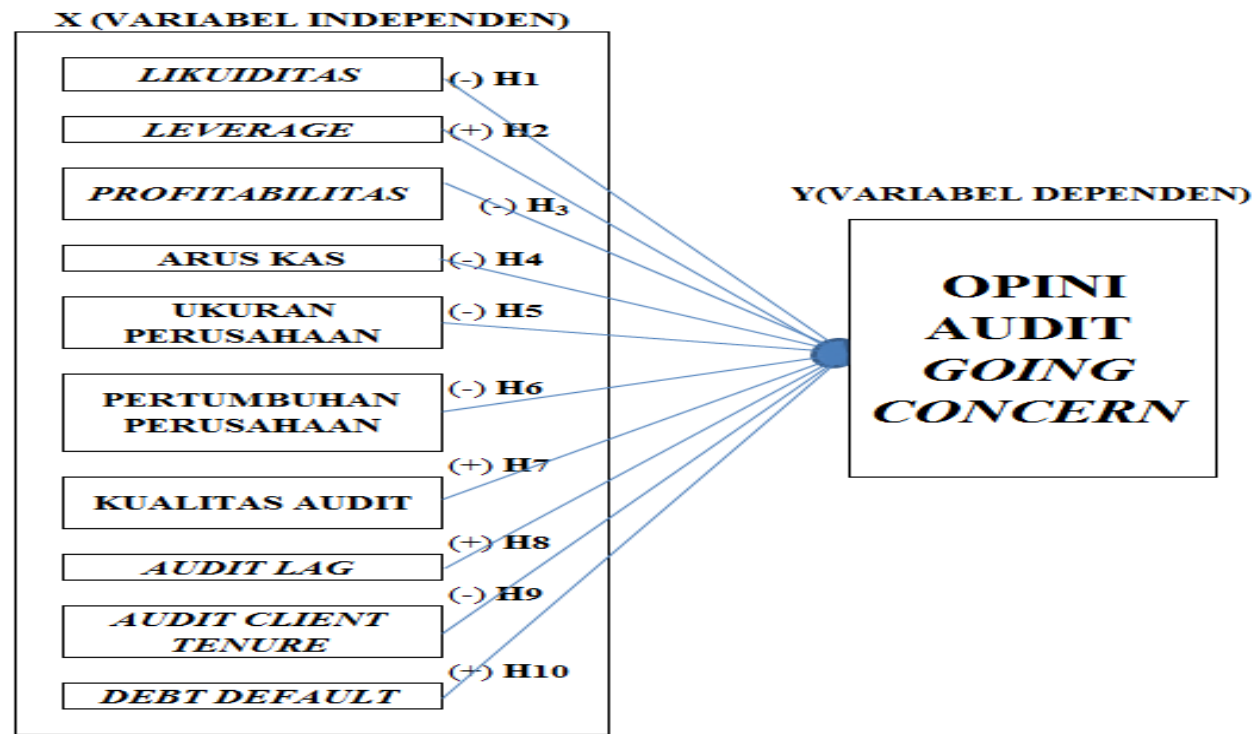

\section{METODOLOGI}

Sifat penelitian ini adalah pengujian hipotesis dengan intervensi minimal dan menggunakan situasi dari lingkungan riil. Jenis penelitian ini adalah meneliti hubungan sebab akibat (kausalitas). Pemilihan obyek penelitian merupakan tahap penting dalam melakukan sebuah penelitian. Obyek penelitian yang digunakan dalam penelitian ini terdiri 
dari opini audit going concern sebagai variabel dependen dan likuiditas, leverage, profitabilitas, arus kas, ukuran perusahaan, pertumbuhan perusahaan, kualitas audit, audit lag, auditor client tenure, debt default sebagai variabel independennya. Unit analisis yang digunakan dalam penelitian seluruh perusahaan yang bergerak di bidang manufaktur yang terdaftar di Bursa Efek Indonesia (BEI) pada tahun 2010 sampai dengan tahun 2013. Berdasarkan data yang terdaftar di BEI tahun 2010 sampai dengan tahun 2013 tercatat ada 148 perusahaan manufaktur yang memenuhi kriteria sampling.

Variabel opini audit going concern diukur dengan menggunakan variabel dummy. Opini audit going concern diberi kode 1, opini audit non going concern diberi kode 0 .

Likuiditas. Rasio likuiditas mengukur sejauh mana perusahaan mampu untuk menyelesaikan liabilitas jangka pendeknya dengan menggunakan aset lancar yang dimiliki. Likuiditas dalam penelitian ini diukur dengan current ratio yaitu aset lancar dibagi liabilitas lancar (Messier et al, 2014:174) :

$$
\text { Current Ratio }=\frac{\text { Current Assets }}{\text { Current Liabilities }}
$$

Leverage. Leverage dalam penelitian ini diukur dengan menggunakan debt ratio yaitu membandingkan antara total liabilitas dengan total aset (Kasmir, 2014:156). Rasio ini mengukur sejauh mana aktiva perusahaan dibelanjai dengan kewajiban yang berasal dari kreditor dan modal sendiri yang berasal dari pemegang saham.

Profitabilitas. Profitabilitas dalam penelitian ini diukur menggunakan rasio laba bersih sebelum pajak dibagi dengan penjualan bersih (Messier, 2014:176).

$$
\text { NIBTS }=\frac{\text { Laba Bersih Sebelum Pajak }}{\text { Peniualan Bersih }}
$$

Arus Kas. Salah satu rasio arus kas yang dapat digunakan oleh auditor untuk menilai kemampuan perusahaan dalam melanjutkan usahanya adalah cash flow to total debt ratio. Rasio ini diukur dengan membandingkan antara arus kas operasi dengan total liabilitas (Hery, 2015:125).

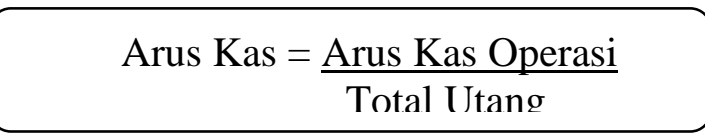

\section{Ukuran perusahaan. Ukuran} perusahaan dalam penelitian ini diukur melalui logaritma total aktiva. Total aktiva dipilih sebagai proksi atas ukuran perusahaan dengan mempertimbangkan bahwa nilai aktiva relatif lebih stabil dibandingkan dengan nilai market capitalized dan penjualan (Sudarmaji dan Sularto, 2007) dalam Widyantari (2011).

Ukuran Perusahaan $=$ Ln $($ Total Asset $)$

Pertumbuhan Perusahaan. Menurut Harahap (2013:309), rasio pertumbuhan perusahaan (growth) menggambarkan persentasi pertumbuhan pos-pos perusahaan dari tahun ke tahun. Dalam penelitian ini pertumbuhan perusahaan diproksikan dengan rasio pertumbuhan penjualan (Harahap, 2013:309).

Pertumbuhan penjualan $=\underline{\text { Penjualan }}_{1}=$ Penjualan $_{\mathrm{t}-1}$ 
Kualitas Audit. Kualitas audit diukur berdasarkan skala auditor. Skala auditor dalam penelitian ini adalah tempat KAP mengaudit laporan keuangan tersebut berasal dari The Big Four atau tidak. Variabel kualitas audit diukur dengan menggunakan variabel dummy, yaitu diberikan kode 1 jika KAP berafiliasi dengan KAP The Big Four, dan diberikan kode 0 jika KAP tidak berafiliasi dengan KAP The Big Four (Setyarno dkk., 2006) dalam Widyantari (2011).

Audit lag. Astuti (2012) menyatakan audit lag adalah jumlah kalender antara tanggal disusunnya laporan keuangan dengan tanggal selesainya pekerjaan lapangan. Audit lag mengindikasikan lamanya waktu penyelesaian audit yang dilakukan oleh auditor (Subyekti dan Widiyanti, 2004) dalam Widyantari (2011).

Audit Client Tenure. Auditor client tenure diukur dengan menghitung tahun dimana KAP yang sama telah melakukan perikatan dengan auditee (Januarti, 2009). Variabel auditor client tenure ini menggunakan skala interval sesuai dengan lama hubungan KAP dengan perusahaan. Auditor Client Tenure diukur dengan menghitung jumlah tahun dimana KAP yang sama telah melakukan perikatan audit terhadap auditee dengan simbol Auditor Client Tenure (ACT). Tahun pertama perikatan dimulai dengan angka 1 dan ditambah dengan satu untuk tahun-tahun berikutnya. Informasi ini dapat dilihat pada laporan auditor independen selama beberapa tahun untuk memastikan lamanya KAP mengaudit perusahaan tersebut.

Debt Default. Menurut Yulius (2009), Debt default diukur menggunakan variabel dummy digunakan $(1=$ status debt default, 0 = tidak debt default) untuk menunjukkan apakah perusahaan dalam keadaan default atau tidak. Status debt default biasanya ada atau terungkap di catatan atas laporan keuangan pada penjelasan atas laporan keuangan (pada pos utang) atau dalam opini audit.

Jenis data yang digunakan dalam penelitian ini adalah data sekunder yaitu berupa laporan keuangan tahunan perusahaan publik yang bergerak di bidang manufaktur serta terdaftar di Bursa Efek Indonesia (BEI) yang merupakan rekaman historis mengenai kondisi keuangan dan kinerja perusahaan. Perusahaan manufaktur yang dipilih sebagai obyek penelitian karena merupakan perusahaan yang paling banyak listing di bursa sehingga memperluas area pemilihan sampel. Data untuk penelitian ini diperoleh dari laporan keuangan tahunan perusahaan publik di bidang manufaktur yang terdaftar di Bursa Efek Indonesia (BEI). Data tersebut yaitu berupa laporan keuangan auditan perusahaan yang dipublikasikan oleh BEI selama tahun 2010-2013. Teknik pemilihan (sampling) yang digunakan adalah teknik purposive sampling. Menurut Kartika (2012), metode purposive sampling yaitu metode pengambilan sampel dengan menggunakan kriteria tertentu.

Metode analisis yang digunakan dalam penelitian ini adalah regresi logistik. 
Pengujian hipotesis dilakukan dengan analisis mutivariat dengan menggunakan regresi logistik (logistic regression). Regresi logistik adalah bentuk khusus analisa regresi dengan variabel dependen bersifat kategori dan variabel independennya bersifat kategori dan gabungan antara metrik dan non metrik. Ghozali (2011:225) menyatakan bahwa regresi logistik ini digunakan untuk menguji apakah probabilitas terjadinya variabel dependen dapat diprediksi dengan variabel independen.

Model regresi logistik yang digunakan untuk menguji hipotesis sebagai berikut :

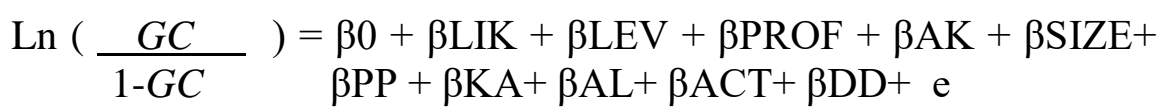

Keterangan:

Ln $(\underline{G C})=$ Probabilita mendapatkan opini audit going concern

$$
1-G C
$$

$\beta 0$

$\beta$ LEV

$\beta A K$

$\beta P P$

$\beta A L$

$\beta \mathrm{DD}$

Residual

\section{HASIL DAN PEMBAHASAN}

Objek penelitian ini adalah perusahaan yang bergerak di bidang manufaktur yang terdaftar di Bursa Efek Indonesia dari tahun 2010 sampai dengan tahun 2013. Sampel yang digunakan dalam penelitian ini adalah diperoleh sebanyak 25 perusahaan manufaktur yang terdaftar di Bursa Efek Indonesia sehingga terdapat 100 unit analisis dalam penelitian ini. Sampel perusahaan tersebut dipilih berdasarkan kriteria pemilihan sampel yang telah ditentukan sebagai berikut:

Tabel 1

Prosedur Pemilihan Sampel

\begin{tabular}{|c|l|c|c|}
\hline & \multicolumn{1}{|c|}{ KRITERIA: } & $\begin{array}{c}\text { Jumlah } \\
\text { Pelanggar } \\
\text { an } \\
\text { Kriteria }\end{array}$ & Akumulasi \\
\hline No & \multicolumn{1}{|c|}{$\begin{array}{c}\text { Perusahaan manufaktur yang terdaftar di Bursa Efek } \\
\text { Indonesia selama periode 2010-2013 }\end{array}$} & 148 \\
\hline $\mathbf{2}$ & Perusahaan sudah terdaftar di Bursa Efek Indonesia (BEI) & 15 & 133 \\
\hline
\end{tabular}




\begin{tabular}{|c|l|c|c|} 
& sebelum tanggal 1 Januari 2010 & 5 & 128 \\
\hline $\mathbf{3}$ & $\begin{array}{l}\text { Perusahaan yang tidak dalam proses delisting dari BEI } \\
\text { selama periode penelitian 2010-2013 }\end{array}$ & 17 & 111 \\
\hline $\mathbf{4}$ & $\begin{array}{l}\text { Perusahaan yang menerbitkan laporan keuangan perusahaan } \\
\text { dengan menggunakan mata uang Rupiah pada periode } \\
\text { penelitian 2010-2013 }\end{array}$ & 3 & 108 \\
\hline $\mathbf{5}$ & $\begin{array}{l}\text { Perusahaan yang menerbitkan laporan keuangan yang } \\
\text { berakhir pada 31 Desember. }\end{array}$ & 82 & 26 \\
\hline $\mathbf{6}$ & $\begin{array}{l}\text { Perusahaan yang mengalami laba bersih negatif selama } \\
\text { periode pengamatan tahun 2010-2013. }\end{array}$ & 1 & 25 \\
\hline $\mathbf{7}$ & $\begin{array}{l}\text { Perusahaan yang menerbitkan laporan keuangan yang telah } \\
\text { diaudit oleh auditor independen yang tersedia dan lengkap }\end{array}$ & \multicolumn{2}{|c|}{$\mathbf{2 5}$} \\
\hline & JUMLAH SAMPEL AKHIR & $\mathbf{1 0 0}$ \\
\hline & TAHUN PENGAMATAN & $\mathbf{2}$ \\
\hline
\end{tabular}

Sumber : Data Sekunder yang diolah Peneliti (2015)

Statistik deskriptif bertujuan untuk memberikan gambaran atau deskripsi mengenai variabel-variabel yang akan diteliti. Pengolahan statistik deskriptif menunjukkan mengenai jumlah sampel yang diteliti, nilai maksimum, nilai minimum, rata-rata, dan standard deviasi dari masing-masing variabel dari tahun 2010-2013. Data yang digunakan dalam penelitian ini diambil dari laporan auditor independen dan laporan keuangan perusahaan. Hasil pengolahan statistik deskriptif dapat dilihat pada tabel 2 sebagai berikut :

Tabel 2

Hasil Output Analisis Deskriptif

Descriptive Statistics

\begin{tabular}{|l|r|r|r|r|r|}
\hline & $\mathrm{N}$ & \multicolumn{1}{|c|}{ Minimum } & Maximum & Mean & Std. Deviation \\
\hline LIK & 100 & 0,15 & 85,41 & 2,994 & 8,798 \\
LEV & 100 & 0,04 & 3,21 & 0,797 & 0,644 \\
PROF & 100 & $-25,40$ & 21,00 & 1,199 & 3,559 \\
AK & 100 & $-1,07$ & 1,09 & 0,039 & 0,261 \\
SIZE & 100 & 23,08 & 29,85 & 27,167 & 1,409 \\
PP & 100 & $-1,00$ & 2,94 & 0,088 & 0,397 \\
AL & 100 & 35,00 & 148,00 & 82,100 & 13,734 \\
ACT & 100 & 1,00 & 4,00 & 2,020 & 1,044 \\
Valid N & 100 & & & & \\
(listwise) & & & & & \\
\hline
\end{tabular}

Sumber: Hasil Pengolahan SPSS 19 
Selain variabel independen yang tidak termasuk dalam kategorikal pada penelitian ini, ada beberapa variabel independen yang masuk dalam kategorikal. Data kategorikal yang diberi kode 1 dan 0 hanya berfungsi sebagai label kategori semata tanpa nilai intrinsik dan tidak memiliki arti apa-apa, oleh sebab itu tidaklah tepat menghitung nilai rata-rata dan standar deviasi dari variabel kategorikal ini. Jadi uji yang sesuai dengan variabel ini adalah melihat distribusi frekuensi melalui tabulasi silang. Adapun hasil crosstab masingmasing variabel kategorikal disajikan pada tabel 3 sebagai berikut:

Tabel 3

\begin{tabular}{|c|c|c|c|c|c|c|}
\hline \multirow{2}{*}{$\begin{array}{l}\mathbf{N} \\
\mathbf{o}\end{array}$} & \multirow[t]{2}{*}{ Variabel } & \multicolumn{2}{|c|}{$\begin{array}{c}\text { Opini Audit Non } \\
\text { Going Concern }\end{array}$} & \multicolumn{2}{|c|}{$\begin{array}{c}\text { Opini Audit Going } \\
\text { Concern }\end{array}$} & \multirow[t]{2}{*}{ Total } \\
\hline & & NGC & $\%$ & GC & $\%$ & \\
\hline \multirow[t]{4}{*}{1} & Kualitas Audit (KA) & & & & & \\
\hline & 0 = KAP non Big Four & 54 & 81,82 & 26 & 76,47 & 80,00 \\
\hline & 1 = KAP Big Four & 12 & 18,18 & 8 & 23,53 & 20,00 \\
\hline & Jumlah & 66 & 100,00 & 34,00 & 100,00 & 100,00 \\
\hline \multirow[t]{4}{*}{2} & Debt Default(DD) & & & & & \\
\hline & $0=$ Non Debt Default & 66 & 100,00 & 9,00 & 26,47 & 75,00 \\
\hline & $1=$ Debt Default & 0 & 0,00 & 25,00 & 73,53 & 25,00 \\
\hline & Jumlah & 66 & 100,00 & 34,00 & 100,00 & 100,00 \\
\hline
\end{tabular}

Sumber: Data Diolah 2015

\section{Hasil Uji Regresi Logistik Menilai Keseluruhan Model}

Penilaian keseluruhan model dilakukan dengan membandingkan nilai antara -2 Log likehood (-2LL) pada awal $($ Block Number $=0)$, dimana model hanya memasukkan konstanta dengan nilai -2 Log likehood (-2LL) pada awal (Block Number = 1), dimana model memasukkan konstanta dan variabel bebas. Hasil pada -2 Log likehood (-2LL) dapat dilihat pada tabel 4 berikut:

Tabel 4

Overall Model Fit

\begin{tabular}{|l|r|}
\hline -2LL awal (Block Number $=0)$ & 128,207 \\
\hline -2LL akhir $($ Block Number $=1)$ & 35,841 \\
\hline
\end{tabular}

Pengujian menunjukkan nilai -2LL awal adalah sebesar 128,207. Setelah dimasukkan sepuluh variabel independen, nilai akhir -2LL mengalami penurunan menjadi 35,841. Penurunan nilai -2 Log Likelihood ini dapat diartikan bahwa penambahan variabel bebas ke dalam model dapat memperbaiki model fit serta menunjukkan model regresi yang lebih baik atau dengan kata lain model yang dihipotesiskan fit dengan data.

Menilai Model Regresi. Kelayakan model regresi dinilai dengan menggunakan Hosmer and Lemeshow's Goodness of Fit Test. Hosmer and Lemeshow's Goodness of Fit Test menguji hipotesis nol bahwa data empiris cocok atau sesuai dengan model 
(tidak ada perbedaan antara model dengan data sehingga model dapat dikatakan fit). Hasil Hosmer and Lemeshow's Goodness of Fit Test dapat dilihat pada Tabel 5 sebagai berikut :

Tabel 5

Hosmer and Lemeshow Test

\begin{tabular}{|l|r|r|c|}
\hline Step & Chi-square & df & \multicolumn{1}{c|}{ Sig. } \\
\hline 1 & 4,834 & & 8 \\
\hline
\end{tabular}

Hasil pengujian menunjukkan bahwa nilai Chi-square dalam Hosmer and Lemeshow Test sebesar 4,834 dengan nilai probabilitas signifikansi 0,775 , dimana 0,775 lebih besar dari 0,05 maka dapat disimpulkan bahwa model mampu memprediksi nilai observasinya atau dapat dikatakan model regresi dapat digunakan dalam analisis selanjutnya, karena cocok dengan data observasinya.

\section{Koefisien Determinasi (Cox and Snell's} $\boldsymbol{R}$ Square dan Nagelkerke's $\boldsymbol{R}$ Square). Koefisien determinasi digunakan untuk menjelaskan seberapa besar variabilitas variabel-variabel independen, yaitu likuiditas, leverage, profitabilitas, arus kas, ukuran perusahaan, pertumbuhan perusahaan, kualitas audit, audit lag, audit client tenure, debt default yang mampu menjelaskan variabilitas variabel independennya, yaitu opini audit going concern. Besarnya nilai koefisien determinasi pada model regresi logistik ditunjukkan oleh nilai Nagelkerke $R$ Square. Besarnya nilai koefisien determinasi pada model regresi logistik ditunjukkan oleh nilai Nagelkerke $R$ Square yang menghasilkan -2 Log Likelihood sebesar 35,841. Nilai Cox and Snell's $R$ Square sebesar 0,603 dan pengaruh yang ditentukan nilai
Nagelkerke R Square dalam periode 2010 sampai dengan 2013 sebesar 83,4\%, sisanya sebesar $16,6 \%$ dijelaskan oleh variabel-variabel lain di luar model penelitian ini.

Uji Multikolinearitas. Model regresi yang baik seharusnya tidak terjadi korelasi sempurna atau mendekati sempurna di antara variabel bebasnya. Pengujian multikolinearitas dalam regresi logistik menggunakan matriks antarvariabel bebas untuk melihat besarnya korelasi antarvariabel bebas didalam penelitian ini adalah LIK, LEV, PROF, AK, SIZE, PP, KA, AL, ACT, DD. Menurut Ghozali (2011:105), jika antar variabel independen ada korelasi yang cukup tinggi diatas 0,90 maka hal ini merupakan indikasi adanya multikolinaritas. Hasil pengujian menunjukkan tidak ada nilai koefisien korelasi antarvariabel yang lebih besar dari 0,90. Dengan demikian dapat disimpulkan bahwa tidak terdapat gejala multikolinearitas yang serius antarvariabel bebas tersebut.

Model Regresi Logistik. Model regresi logistik dapat dibentuk dengan melihat pada nilai estimasi parameter dalam Variables in The Equation. Estimasi 
parameter dari model dan tingkat sebagai berikut: signifikansinya dapat dilihat pada tabel 8

Tabel 8

Variables in the Equation

\begin{tabular}{|c|c|c|c|}
\hline Variabel & Koefisien & Sign. 5\% & Keputusan \\
\hline Constanta & $-7,579$ & 0,009 & \\
\hline LIK & $-0,206$ & 0,332 & Ho gagal ditolak \\
\hline LEV & 2,272 & 0,031 & Ho ditolak \\
\hline PROF & $-0,307$ & 0,125 & Ho gagal ditolak \\
\hline AK & $-5,694$ & 0,004 & Ho ditolak \\
\hline SIZE & 0,504 & 0,079 & Ho gagal ditolak \\
\hline PP & $-1,925$ & 0,116 & Ho gagal ditolak \\
\hline KA & $-1,309$ & 0,251 & Ho gagal ditolak \\
\hline AL & 0,043 & 0,046 & Ho ditolak \\
\hline ACT & 0,167 & 0,365 & Ho gagal ditolak \\
\hline DD & 22,113 & 0,499 & Ho gagal ditolak \\
\hline
\end{tabular}

Sumber: Diolah Peneliti, 2015

Model regresi yang terbentuk berdasarkan nilai estimasi parameter dalam Variables in The Equation adalah sebagai berikut :

$$
\begin{aligned}
\operatorname{Ln}\left(\frac{\mathrm{GC}}{1-\mathrm{GC}}\right)= & -7,579-0,206 \mathrm{LIK}+2,272 \mathrm{LEV}-0,307 \mathrm{PROF} \\
& -5,694 \mathrm{AK}+0,504 \mathrm{SIZE}-1,925 \mathrm{PP}-1,309 \mathrm{KA} \\
& +0,043 \mathrm{AL}+0,167 \mathrm{ACT}+22,113 \mathrm{DD}+\mathrm{e}
\end{aligned}
$$

Hasil Pengujian Hipotesis. Pengujian hipotesis dilakukan dengan cara membandingkan antara tingkat signifikansi (sig) dengan tingkat kesalahan $(\alpha)=5 \%$. Berdasarkan Tabel 4.8 dapat diinterpretasikan hasil sebagai berikut ini.

\section{Hipotesis Pertama $\left(\mathbf{H}_{1}\right)$ :} Likuiditas berpengaruh negatif pada opini audit going concern. Hasil pengujian menunjukkan variabel likuiditas (LIK) yang diproksikan dengan current ratio memiliki tingkat signifikansi 0,332 yang lebih besar dari $\alpha \quad(5 \%)$ dengan nilai koefisien regresi negatif sebesar $-0,206$. Berdasarkan hal tersebut dapat disimpulkan bahwa variabel likuiditas tidak berpengaruh pada opini audit going concern atau dengan kata lain hipotesis pertama $\left(\mathrm{H}_{1}\right)$ gagal ditolak.

2. Hipotesis Kedua $\left(\mathrm{H}_{2}\right)$ : Leverage berpengaruh positif pada opini audit going concern. Hasil pengujian menunjukkan variabel leverage (LEV) yang diproksikan 
dengan debt ratio memiliki tingkat signifikansi 0,031 yang lebih kecil dari $\alpha(5 \%)$ dengan nilai koefisien regresi positif sebesar 2,272. Berdasarkan hal tersebut dapat disimpulkan bahwa variabel leverage berpengaruh positif pada opini audit going concern atau dengan kata lain hipotesis kedua $\left(\mathrm{H}_{2}\right)$ ditolak.

\section{Hipotesis Ketiga $\left(\mathrm{H}_{3}\right)$ :} Profitabilitas berpengaruh negatif pada opini audit going concern. Hasil pengujian menunjukkan variabel profitabilitas (PROF) yang diproksikan dengan NIBTS memiliki tingkat signifikansi 0,125 yang lebih besar dari $\alpha(5 \%)$ dengan nilai koefisien regresi negatif sebesar $-0,307$. Berdasarkan hal tersebut dapat disimpulkan bahwa variabel profitabilitas tidak berpengaruh pada opini audit going concern atau dengan kata lain hipotesis ketiga $\left(\mathrm{H}_{3}\right)$ gagal ditolak.

4. Hipotesis Keempat $\left(\mathrm{H}_{4}\right)$ : Arus kas berpengaruh negatif pada opini audit going concern. Hasil pengujian menunjukkan variabel arus kas (AK) yang diproksikan dengan cash flow to debt ratio memiliki tingkat signifikansi 0,004 yang lebih kecil dari $\alpha(5 \%)$ dengan nilai koefisien regresi negatif sebesar -5,694. Berdasarkan hal tersebut dapat disimpulkan bahwa variabel arus kas berpengaruh negatif pada opini audit going concern atau dengan kata lain hipotesis keempat $\left(\mathrm{H}_{4}\right)$ ditolak.
5. Hipotesis Kelima $\left(\mathbf{H}_{5}\right)$ : Ukuran perusahaan berpengaruh negatif pada opini audit going concern. Hasil pengujian menunjukkan variabel ukuran perusahaan yang diproksikan dengan total aktiva memiliki tingkat signifikansi 0,079 yang lebih besar dari $\alpha \quad(5 \%)$ dengan nilai koefisien regresi positif sebesar 0,504. Berdasarkan hal tersebut dapat disimpulkan bahwa variabel ukuran perusahaan tidak berpengaruh pada opini audit going concern atau dengan kata lain hipotesis kelima $\left(\mathrm{H}_{5}\right)$ gagal ditolak.

6. Hipotesis keenam $\left(\mathrm{H}_{6}\right)$ : Pertumbuhan perusahaan berpengaruh negatif pada opini audit going concern. Hasil pengujian menunjukkan variabel pertumbuhan perusahaan yang diproksikan dengan pertumbuhan penjualan memiliki tingkat signifikansi 0,116 yang lebih besar dari $\alpha(5 \%)$ dengan nilai koefisien regresi negatif sebesar $-1,925$. dengan Berdasarkan hal tersebut dapat disimpulkan bahwa variabel pertumbuhan perusahaan tidak berpengaruh pada opini audit going concern atau dengan kata lain hipotesis keenam $\left(\mathrm{H}_{6}\right)$ gagal ditolak.

7. Hipotesis Ketujuh $\left(\mathbf{H}_{7}\right)$ : Kualitas audit berpengaruh negatif pada opini audit going concern. Hasil pengujian menunjukkan variabel kualitas audit yang diukur dari berafiliasi atau tidak dengan KAP Big Four memiliki tingkat signifikansi 0,251 yang lebih besar 
dari $\alpha(5 \%)$ dengan nilai koefisien regresi negatif sebesar $-1,309$. Berdasarkan hal tersebut dapat disimpulkan bahwa variabel kualitas audit tidak berpengaruh pada opini audit going concern atau dengan kata lain hipotesis ketujuh $\left(\mathrm{H}_{7}\right)$ gagal ditolak.

8. Hipotesis Kedelapan $\left(\mathrm{H}_{8}\right)$ : Audit lag berpengaruh positif pada opini audit going concern. Hasil pengujian menunjukkan variabel audit lag (AL) memiliki tingkat signifikansi 0,046 yang lebih kecil dari $\alpha(5 \%)$ dengan nilai koefisien regresi positif sebesar 0,043 . Berdasarkan hal tersebut dapat disimpulkan bahwa variabel audit lag berpengaruh positif pada opini audit going concern atau dengan kata lain hipotesis kedelapan $\left(\mathrm{H}_{8}\right)$ ditolak.

9. Hipotesis Kesembilan $\left(\mathbf{H}_{9}\right)$ : Auditor Client Tenure berpengaruh negatif pada opini audit going concern. Hasil pengujian menunjukkan variabel auditor client tenure memiliki tingkat signifikansi 0,365 yang lebih besar dari $\alpha(5 \%)$ dengan nilai koefisien regresi positif sebesar 0,167 . Berdasarkan hal tersebut dapat disimpulkan bahwa variabel auditor client tenure tidak berpengaruh pada opini audit going concern atau dengan kata lain hipotesis kesembilan $\left(\mathrm{H}_{9}\right)$ gagal ditolak.

10. Hipotesis Kesepuluh $\left(\mathrm{H}_{10}\right):$ Debt Default berpengaruh positif pada opini audit going concern. Hasil pengujian menunjukkan variabel debt default memiliki tingkat signifikansi 0,499 yang lebih besar dari $\alpha(5 \%)$ dengan nilai koefisien regresi positif sebesar 22,113. Berdasarkan hal tersebut dapat disimpulkan bahwa variabel debt default tidak berpengaruh pada opini audit going concern atau dengan kata lain hipotesis kesepuluh $\left(\mathrm{H}_{10}\right)$ gagal ditolak

\section{SIMPULAN}

Berdasarkan analisis dan pembahasan yang dilakukan pada penelitian mengenai pengaruh likuiditas, leverage, profitabilitas, arus kas, ukuran perusahaan, pertumbuhan perusahaan, kualitas audit, audit lag, auditor client tenure, debt default terhadap penerimaan opini audit going concern pada perusahaan manufaktur yang terdaftar di Bursa Efek Indonesia periode 2010-2013, maka didapat kesimpulan, yaitu: (1) Likuiditas tidak berpengaruh terhadap penerimaan opini audit going concern. (2) Leverage berpengaruh positif terhadap penerimaan opini audit going concern.(3) Profitabilitas tidak berpengaruh terhadap penerimaan opini audit going concern. (4) Arus kas berpengaruh negatif terhadap penerimaan opini audit going concern.(5) Ukuran Perusahaan tidak berpengaruh terhadap penerimaan opini audit going concern. (6)Pertumbuhan Perusahaan tidak berpengaruh terhadap penerimaan opini audit going concern. (7) Kualitas Audit tidak berpengaruh terhadap penerimaan opini audit going concern. (8) Audit Lag berpengaruh positif terhadap penerimaan opini audit going concern.(9) Auditor Client Tenure tidak berpengaruh terhadap 
penerimaan opini audit going concern. (10) Debt Default tidak berpengaruh terhadap penerimaan opini audit going concern.

\section{DAFTAR PUSTAKA}

Agoes, Sukrisno. 2012. Auditing : Petunjuk Praktis Pemeriksaan Akuntan oleh Akuntan Publik. Edisi Keempat. Jilid 1. Jakarta: Salemba Empat.

Astuti, Irtani Retno. 2012. "Pengaruh Faktor Keuangan dan Non Keuangan Terhadap Penerimaan Opini Audit Going Concern". Diponegoro Journal of Accounting, Vol. 1. No. 2. pp. 110. (http://ejournals1.undip.ac.id/index.php/accounti $n g$ ).

Carey, Peter J., Marshall A. Geiger and Brendan T. O'Connell. 2008. Costs Associated With Going Concern Modified Audit Opinions: An Analysis of the Australian Audit Market. Abacus Vol. 44 No. 1, page 61-81.

Coelho, Luis M.S., Ruben M.T. Peixinho, and Siri Terjensen. 2012. Going Concern Opinion Are Not Bad News: Evidence From Industry Rivals. Journal Department of Economic, Technical University of Lisbon, ISSN No. 0874-4558.

Dewayanto, Totok. 2011. "Analisis Faktor-Faktor Yang Mempengaruhi Penerimaan Opini Audit Going Concern Pada Perusahaan Manufaktur Yang Terdaftar di Bursa Efek Indonesia. Fokus Ekonomi, Vol. 6 No. 1, Juni 2011:81-104.
Ghozali, Imam. 2011. Aplikasi Analisis Multivariate dengan Program SPSS. Semarang : Badan Penerbit Universitas Diponegoro.

Haron, Hasnah, Bambang Hartadi, Mahfooz Ansari, and Ishak Ismail. (2009)"Factors Influencing Auditor's Going Concern Opinion" Asian Academy of Management Journal, Vol. 14 No. $1: 1-19$

Institut Akuntan Publik Indonesia. 2011. Standar Profesional Akuntan Publik. Jakarta : Salemba Empat.

Januarti, Indira. 2009. Analisis Pengaruh Faktor Perusahaan, Kualitas Auditor, Kepemilikan Perusahaan Terhadap Penerimaan Opini Audit Going Concern (Perusahaan Manufaktur yang Terdaftar di Bursa Efek Indonesia). Makalah Disampaikan dalam Simposium Nasional Akuntansi XII. Palembang:4-6 November.

Junaidi dan Jogiyanto Hartono. 2010. "Faktor Non Keuangan pada Opini Going Concern". Simposium Nasional Akuntansi XIII, Purwokerto.

Kartika, Andi. 2012. "Pengaruh Kondisi Keuangan dan Non Keuangan Terhadap Penerimaan Opini Going Concern Pada Perusahaan Manufaktur di BEI. Dinamika Akuntansi, Keuangan dan Perbankan, Vol. 1 No. 1, Hlm 2540.

Masyitoh, Oni Currie and Desi Adhariani. 2010. The analysis of Determinants of Going Concern Audit Report. Journal of Modern 
Accounting and Auditing. Vol.6 No. 4:26-37.

Novietta, Liza. 2009. Pengaruh Going Concern Terhadap Opini Auditor Pada Perusahaan Manufaktur Publik Yang Terdaftar di Bursa Efek Jakarta. Jurnal Keuangan dan Bisnis, Vol. 1 No.1, November 2009. STIE Harapan Medan.

Peraturan Menteri Keuangan Nomor: 17/PMK.01/2008 Tentang Jasa Akuntan Publik. Available at: http://www.depkeu.go.id.

Praptitorini, Myrna dan Januarti. 2011. "Analisis Pengaruh Kualitas Audit, Debt Default Dan Opinion Shopping Terhadap Penerimaan Opini Going Concern". Jurnal Akuntansi dan Keuangan Indonesia, Volume 8-No. 1, Juni 2011. Universitas Diponegoro.

Putrady, Gea Cherlita, Haryanto. 2014. "Analisis Faktor Keuangan dan Non Keuangan yang Mempengaruhi Penerimaan Opini Audit Going Concern". Diponegoro Journal of Accounting, Vol. 3 No. 2, pp:112. (http://ejournal-sl. undip.ac.id/index.php/accounting)

Rahman, Abdul dan Baldric Siregar. 2012. "Faktor-Faktor Yang Mempengaruhi Kecenderungan Penerimaan Opini Audit Going Concern Pada Perusahaan Manufaktur Yang Terdaftar di Bursa Efek Indonesia". Jurnal Akuntansi. Sekolah Tinggi Ilmu Ekonomi YKPN Yogyakarta.
Setyarno, Eko Budi, Indira Januarti, dan Faisal. 2006. Pengaruh Kualitas Audit, Kondisi Keuangan Perusahaan, Opini Audit Tahun Sebelumnya, Pertumbuhan Perusahaan terhadap Opini Audit Going Concern. Makalah Disampaikan dalam Simposium Nasional Akuntansi IX. Padang:23-26 Agustus.

Socol, Adela. 2010. Significant Doubt About the Going Concern Assumption in Audit. Annales Universitas Apulensis Series Oeconomica 12(1), Page 291-299.

Solikhah, Badingatus dan Kiswanto. 2010. "Pengaruh Kondisi Keuangan, Pertumbuhan dan Opini Audit Tahun Sebelumnya Terhadap Opini Audit Going Concern". Jurnal Dinamika Akuntansi, Vol. 2 No.1, hlm 5664. Universitas Negeri Semarang.

Susanto, Yulius Kurnia. 2009. FaktorFaktor yang Mempengaruhi Penerimaan Opini Audit Going Concern Pada Perusahaan Publik Sektor Manufaktur. Jurnal Bisnis dan Akuntansi, Vol 11, No.3 : 155-173.

Suryani, Lana. 2014. "Praktik Manajemen Laba, Pertumbuhan Perusahaan, Price Earning Ratio, Audit Report Lag Terkait Penerimaan Opini Audit Going Concern". E-Jurnal Akuntansi Universitas Udayana 8.1(2014): 154-170, ISSN:2302-8556.

Tuanakotta, Theodorus M. 2013. Audit Berbasis ISA (International Standars on Auditing). Jakarta: Salemba Empat. 
Venuti, Elizabeth K. 2007."The Going Concern Assumption Revisited : Assessing a Company's Future Viability: The CPA Journal Online.

Verdiana, Komang Anggita dan I Made Karya Utama. 2013. Pengaruh Reputasi Auditor, Disclosure, Audit Client Tenure Pada Kemungkinan Pengungkapan Opini Audit Going Concern. EJurnal Akuntansi Universitas Udayana 5.3:530-543.ISSN :2302-8556.

Warnida. 2011. "Analisis Faktor-Faktor Yang Mempengaruhi Penerimaan Opini Audit Going Concern (Studi Empiris Pada Perusahaan Yang Listing di BEI). Jurnal Akuntansi \& Manajemen Vol 6 No. 1 Juni 2011 ISSN 1858-3687 hal 30-43. Fakultas Ekonomi Universitas Andalas.

Widyantari, A.A.Ayu Putri. 2011. Opini Audit Going Concern dan FaktorFaktor Yang Memengaruhi: Studi Pada Perusahaan Manufaktur di Bursa Efek Indonesia. Tesis.Universitas Udayana. Denpasar.

Yunida, Riswan dan M. Wahyu Wardhana. 2013. "Pengaruh Kualitas Audit, Kondisi Keuangan Perusahaan, Opini Audit Tahun Sebelumnya, Pertumbuhan Perusahaan Terhadap Opini Audit Going Concern". Jurnal Intekna, Tahun XIII, No. 1, Mei 2013:5461. 